\title{
EDITORIAL
}

\section{Mast cell regulation of airway smooth muscle function in asthma}

\author{
P. Bradding
}

A sthma is a common disease affecting $\leqslant 10 \%$ of the adult Western population [1, 2]. It is characterised by the presence of variable and potentially reversible airflow obstruction, which occurs as the result of bronchoconstriction, airway mucus plugging and airway oedema. Pathologically there is evidence of airway inflammation and remodelling [37]. The mucosal inflammatory infiltrate commonly comprises activated T-cells, eosinophils and mast cells, while the accompanying structural changes include subepithelial collagen deposition, goblet cell- and mucous gland-hyperplasia, airway smooth muscle (ASM) hypertrophy and ASM hyperplasia.

An important physiological feature of asthma is the presence of bronchial hyperresponsiveness (BHR) [8]. This means there is an exaggerated bronchoconstrictor response of the ASM to direct and indirect stimuli such as histamine and exercise, respectively. While BHR is aggravated in the presence of classic allergic eosinophilic airway inflammation, it persists once this inflammation is controlled and is not present in patients with eosinophilic bronchitis $[8,9]$. This suggests that there is either a fundamental abnormality of ASM behaviour in asthmatic subjects or that there are interacting factors that have not been previously recognised. In support of the former, several phenotypic differences are evident in ASM cells cultured from the airways of asthmatic subjects. For example, when compared with normal ASM cells, cultured asthmatic ASM cells proliferate faster due to an altered pattern of matrix protein deposition [10, 11], secrete greater amounts of connective tissue-derived growth factor in response to transforming growth factor- $\beta$ stimulation [12], and secrete markedly increased amounts of the chemokine CXCL10 in response to activation by cytokines [13]. There is decreased expression of prostaglandin (PG) $\mathrm{E}_{2}$ by the asthmatic ASM [14], and proliferation of asthmatic ASM is not inhibited by corticosteroids due to impaired expression of the transcription factor CCAAT/enhancer binding protein- $\alpha$ [15]. It is remarkable that these differences are evident after several passages in culture; moreover, these differences support the view that there is, in part, a primary ASM abnormality in asthma.

Mast cells play a significant role in the pathophysiology of asthma due to their ability to release a host of pleiotropic

STATEMENT OF INTEREST: None declared

CORRESPONDENCE: P. Bradding, Dept of Respiratory Medicine, Glenfield Hospital, Groby Rd, Leicester, LE3 9QP, UK. Fax: 44 1162502787. E-mail: pbradding@hotmail.com autacoid mediators, proteases and cytokines in response to activation by both immunoglobulin (Ig)E-dependent and diverse nonimmunological stimuli [16, 17]. For example, following laboratory allergen challenge, secretion of the autacoid mediators histamine, $\mathrm{PGD}_{2}$ and leukotriene $(\mathrm{LT}) \mathrm{C}_{4}$ induces bronchoconstriction, mucus secretion and mucosal oedema, thus contributing to acute symptoms. Mast cellderived cytokines include interleukin (IL)-4, IL-5 and IL-13, which regulate both $\operatorname{IgE}$ synthesis and the development of eosinophilic inflammation [18]. In addition, the mast cell neutral proteases, tryptase and chymase, interact with many cells that potentially contribute to airway wall remodelling. Importantly, in chronic asthma, mast cells within the bronchial mucosa are in an "activated" secretory state, with evidence of ongoing mediator release and cytokine synthesis [19-22].

Mast cells are found adjacent to blood vessels in the lamina propria in normal human airways, but in asthma they migrate into three key structures: the airway epithelium [23]; the airway mucous glands [24]; and the ASM [25]. This anatomical relocation places the mast cell within several dysfunctional airway elements and suggests that the targeted delivery of their mediators is likely to be central to the disordered airway physiology. Of particular interest in relation to bronchoconstriction and BHR is the presence of mast cells within the ASM bundles. Eosinophilic bronchitis is a common cause of cough and is characterised by the presence of a sputum eosinophilia occurring in the absence of variable airflow obstruction or BHR [9]. A detailed comparison of the immunopathology of asthma and eosinophilic bronchitis has revealed an identical pathology in terms of T-cell infiltration, activation status and phenotype, eosinophil infiltration and activation, mucosal mast cell numbers, T-helper cell (Th)2 cytokine expression, epithelial integrity, sub-basement membrane collagen deposition and mediator concentrations, including histamine and $\mathrm{PGD}_{2}[25-$ 27]. This suggests that many of the immunopathological features previously attributed as causing asthma may not be as important for the development of airflow obstruction, BHR and remodelling as previously suggested. The striking difference between the pathology of asthma and eosinophilic bronchitis resided within the ASM bundles, which contained numerous mast cells in asthma patients but virtually none in normal subjects or patients with eosinophilic bronchitis [25]. The majority of these mast cells contained both tryptase and chymase, and expressed IL-4 and IL-13 but not IL-5. Interestingly, there were almost no T-cells or eosinophils in the smooth muscle of any of the study groups. There was a significant correlation between ASM mast cell number and 
BHR within the asthmatic group supporting the view that this observation is of functional relevance. Such initial findings have been confirmed by several independent groups [28-31] and it has recently been shown that the mast cells within the ASM bundles in asthma demonstrate ultrastructural features of activation [31]. These studies suggest that ASM infiltration by mast cells is one of the critical determinants of the asthmatic phenotype [28-31].

The specific recruitment of mast cells to the ASM in asthma raises several important questions; in particular, whether the cells interact, and if so, what are the functional consequences for airway function? Studies examining whole cell interactions in vitro are sparse. However, human lung mast cells adhere to ASM cells, in part, via an interesting molecule known as tumour suppressor in lung cancer-1, suggesting that specific cellular cross-talk is likely [32]. In addition, potential mechanisms of mast cell recruitment by the ASM have been identified [13] and inhibition of this recruitment may offer a new angle on asthma therapy [33]. In contrast, it has been known for several years that numerous mast cell-derived mediators directly affect ASM function when examined in isolation. For example, the mast cell autacoid mediators histamine, $\mathrm{PGD}_{2}$ and $\mathrm{LTC}_{4}$ are all potent agonists for ASM contraction, and exogenously administered tryptase induces bronchoconstriction and BHR in response to histamine in dogs and sheep [34, 35]. In vitro, tryptase potentiates the contractile response of sensitised bronchi to histamine [36] and induces proliferation of human ASM $[37,38]$. Instillation of Th2 cell conditioned medium to the airways of naïve mice induces BHR within $6 \mathrm{~h}$, and requires expression of the IL- 4 receptor $\alpha$-subunit and signal transducer and activator of transcription (STAT)6, suggesting a critical role for IL-4 and/or IL-13. Both of these ILs produce similar effects when administered individually [39]. TNF- $\alpha$ induces BHR in normal subjects and exacerbates BHR in patients with asthma [40,41], while blocking tumour necrosis factor (TNF)- $\alpha$ activity in asthma patients improves BHR $[42,43]$. Human lung mast cells are a source of IL-4, IL-13 and TNF- $\alpha[23,44-46]$, which suggests a further mechanism through which these cells could contribute to the development of BHR.

In the present issue of the European Respiratory Journal, CHHABRA et al. [47] have examined the ability of two mast cell mediators, histamine and tryptase, to modify the synthetic ability of the ASM derived from both asthmatic and nonasthmatic subjects [47]. Specifically, they examined the release of the cytokine granulocyte-macrophage colony-stimulating factor (GM-CSF) and the RANTES (regulated on activation, normal T-cell expressed and secreted) chemokine. The nonasthmatic subjects were patients undergoing lung transplantation for a variety of end-stage lung diseases or resection for carcinoma, while the asthmatic ASM was obtained at bronchoscopy. However, no important differences in secretory responses were found between the two groups, so it is unlikely that any asthmaspecific effects were missed. The main observation from the study was that histamine potentiated IL- $1 \beta$-induced GM-CSF production but inhibited TNF- $\alpha$-induced RANTES production. In contrast, tryptase only increased GM-CSF secretion after stimulation by both IL-1 $\beta$ and TNF- $\alpha$, and did not affect RANTES secretion. Pharmacological blockade suggested that the effects of histamine were predominantly mediated via the
$\mathrm{H} 1$ and not the $\mathrm{H} 2$ receptor. This was unexpected as CHHABRA et al. [47] predicted that stimulation of $\mathrm{H} 2$ receptors would increase intracellular cyclic adenosine monophosphate and thus inhibit GM-CSF release, while at the same time potentiating RANTES release. The authors therefore proposed that the H1-mediated effects predominated and occur via activation of H1-coupled phospholipase C. However, it must be borne in mind that G-protein coupled receptors (GPCRs), such as $\mathrm{H} 1$ and $\mathrm{H} 2$, that were once thought to mediate all their effects via modulation of intracellular cyclic nucleotides are now known to couple to many diverse signalling pathways [48]. For example, these include the membrane-delimited modulation of numerous ion channels involved in the regulation of intracellular calcium signals $[49,50]$.

The biological significance of the observations of CHHABRA et al. [47] is uncertain. They highlight how the behaviour of cells cannot always be readily predicted and that the potential effects of mast cells on ASM function are undoubtedly complex. It is possible that the effects of histamine and tryptase in combination may differ from those of the individual mediators alone, for example via GPCR cross-talk, and so it would have been interesting for the authors to also examine this. It is also possible that the complex milieu of mediators released from intact mast cells will produce yet different effects, so in the future it will be important to study these cells in co-culture.

In summary, the location of mast cells within the airway smooth muscle bundles is likely to be important for the pathophysiology of asthma and may occur in response to, with subsequent aggravation of, an underlying abnormality in the behaviour of asthmatic airway smooth muscle. Understanding the consequences of this cellular interaction through the type of study by CHHABRA et al. [47] may offer new approaches to the treatment of this common and chronic disease.

\section{REFERENCES}

1 Brogger J, Bakke P, Eide GE, Johansen B, Andersen A, Gulsvik A. Long-term changes in adult asthma prevalence. Eur Respir J 2003; 21: 468-472.

2 Stock S, Redaelli M, Luengen M, Wendland G, Civello D, Lauterbach KW. Asthma: prevalence and cost of illness. Eur Respir J 2005; 25: 47-53.

3 James AL, Elliot JG, Abramson MJ, Walters EH. Time to death, airway wall inflammation and remodelling in fatal asthma. Eur Respir J 2005; 26: 429-434.

4 Boxall C, Holgate ST, Davies DE. The contribution of transforming growth factor- $\beta$ and epidermal growth factor signalling to airway remodelling in chronic asthma. Eur Respir J 2006; 27: 208-229.

5 Fixman ED, Stewart A, Martin JG. Basic mechanisms of development of airway structural changes in asthma. Eur Respir J 2007; 29: 379-389.

6 Berry M, Hargadon B, Morgan A, et al. Alveolar nitric oxide in adults with asthma: evidence of distal lung inflammation in refractory asthma. Eur Respir J 2005; 25: 986-991.

7 Green RH, Brightling CE, McKenna S, et al. Comparison of asthma treatment given in addition to inhaled corticoster- 
oids on airway inflammation and responsiveness. Eur Respir J 2006; 27: 1144-1151.

8 Cockcroft DW, Davis BE. Mechanisms of airway hyperresponsiveness. J Allergy Clin Immunol 2006; 118: 551-559.

9 Brightling CE, Ward R, Goh KL, Wardlaw AJ, Pavord ID. Eosinophilic bronchitis is an important cause of chronic cough. Am J Respir Crit Care Med 1999; 160: 406-410.

10 Johnson PR, Roth M, Tamm M, et al. Airway smooth muscle cell proliferation is increased in asthma. Am J Respir Crit Care Med 2001; 164: 474-477.

11 Johnson P, Burgess J, Underwood P, et al. Extracellular matrix proteins modulate asthmatic airway smooth muscle cell proliferation via an autocrine mechanism. J Allergy Clin Immunol 2004; 113: 690-696.

12 Burgess JK, Johnson PRA, Ge Q, et al. Expression of connective tissue growth factor in asthmatic airway smooth muscle cells. Am J Respir Crit Care Med 2003; 167: 71-77.

13 Brightling CE, Ammit AJ, Kaur D, et al. The CXCL10/ CXCR3 axis mediates human lung mast cell migration to asthmatic airway smooth muscle. Am J Respir Crit Care Med 2005; 171: 1103-1108.

14 Chambers LS, Black JL, Ge Q, et al. PAR-2 activation, PGE2, and COX-2 in human asthmatic and nonasthmatic airway smooth muscle cells. Am J Physiol Lung Cell Mol Physiol 2003; 285: L619-L627.

15 Roth M, Johnson PRA, Borger $\mathrm{P}$, et al. Dysfunctional Interaction of $\mathrm{C} / \mathrm{EBP} \alpha$ and the glucocorticoid receptor in asthmatic bronchial smooth-muscle cells. $N$ Engl J Med 2004; 351: 560-574.

16 Cruse G, Kaur D, Yang W, Duffy SM, Brightling CE, Bradding P. Activation of human lung mast cells by monomeric immunoglobulin E. Eur Respir J 2005; 25: 858-863.

17 Bradding P, Walls AF, Holgate ST. The role of the mast cell in the pathophysiology of asthma. J Allergy Clin Immunol 2006; 117: 1277-1284.

18 Bradding P, Holgate ST. Immunopathology and human mast cell cytokines. Crit Rev Oncol Haematol 1999; 31: 119-133.

19 Flint KC, Leung KB, Hudspith BN, Brostoff J, Pearce FL, Johnson NM. Bronchoalveolar mast cells in extrinsic asthma: a mechanism for the initiation of antigen specific bronchoconstriction. Br Med J 1985; 291: 923-926.

20 Broide DH, Gleich GJ, Cuomo AJ, et al. Evidence of ongoing mast cell and eosinophil degranulation in symptomatic asthma airway. J Allergy Clin Immunol 1991; 88: 637-648.

21 Beasley R, Roche WR, Roberts JA, Holgate ST. Cellular events in the bronchi in mild asthma and after bronchial provocation. Am Rev Respir Dis 1989; 139: 806-817.

22 Ying S, Humbert M, Barkans J, et al. Expression of IL-4 and IL-5 mRNA and protein product by CD4+ and CD8+ T cells, eosinophils, and mast cells in bronchial biopsies obtained from atopic and nonatopic (intrinsic) asthmatics. J Immunol 1997; 158: 3539-3544.

23 Bradding P, Roberts JA, Britten KM, et al. Interleukin-4, -5, and -6 and tumor necrosis factor-alpha in normal and asthmatic airways: evidence for the human mast cell as a source of these cytokines. Am J Respir Cell Mol Biol 1994; 10: 471-480.

24 Carroll NG, Mutavdzic S, James AL. Increased mast cells and neutrophils in submucosal mucous glands and mucus plugging in patients with asthma. Thorax 2002; 57: 677-682.
25 Brightling CE, Bradding P, Symon FA, Holgate ST, Wardlaw AJ, Pavord ID. Mast cell infiltration of airway smooth muscle in asthma. N Engl J Med 2002; 346: 1699-1705.

26 Brightling CE, Symon FA, Birring SS, Bradding P, Wardlaw AJ, Pavord ID. Comparison of airway immunopathology of eosinophilic bronchitis and asthma. Thorax 2003; 58: 528-532.

27 Brightling CE, Symon FA, Birring SS, Bradding P, Pavord ID, Wardlaw AJ. Th2 cytokine expression in bronchoalveolar lavage fluid T lymphocytes and bronchial submucosa is a feature of asthma and eosinophilic bronchitis. J Allergy Clin Immunol 2002; 110: 899-905.

28 Amin K, Janson C, Boman G, Venge P. The extracellular deposition of mast cell products is increased in hypertrophic airways smooth muscle in allergic asthma but not in nonallergic asthma. Allergy 2005; 60: 1241-1247.

29 Berger P, Girodet PO, Begueret $\mathrm{H}$, et al. Tryptasestimulated human airway smooth muscle cells induce cytokine synthesis and mast cell chemotaxis. FASEB J 2003; 17: 2139-2141.

30 El-Shazly A, Berger P, Girodet PO, et al. Fraktalkine produced by airway smooth muscle cells contributes to mast cell recruitment in asthma. J Immunol 2006; 176: 1860-1868.

31 Begueret $H$, Berger P, Vernejoux JM, Dubuisson L, Marthan R, Tunon-De-Lara JM. Inflammation of bronchial smooth muscle in allergic asthma. Thorax 2007; 62: 8-15.

32 Yang W, Kaur D, Okayama Y, et al. Human lung mast cells adhere to human airway smooth muscle, in part, via tumor suppressor in lung cancer-1. J Immunol 2006; 176: 1238-1243.

33 Cruse G, Duffy SM, Brightling CE, Bradding P. Functional KCa3.1 K+ channels are required for human lung mast cell migration. Thorax 2006; 61: 880-885.

34 Sekizawa K, Caughey GH, Lazarus SC, Gold WM, Nadel JA. Mast cell tryptase causes airway smooth muscle hyperresponsiveness in dogs. J Clin Invest 1989; 83: 175-179.

35 Molinari JF, Scuri M, Moore WR, Clark J, Tanaka R, Abraham WM. Inhaled tryptase causes bronchoconstriction in sheep via histamine release. Am J Respir Crit Care Med 1996; 154: 649-653.

36 Berger P, Compton SJ, Molimard M, et al. Mast cell tryptase as a mediator of hyperresponsiveness in human isolated bronchi. Clin Exp Allergy 1999; 29: 804-812.

37 Berger P, Perng DW, Thabrew H, et al. Tryptase and agonists of PAR-2 induce the proliferation of human airway smooth muscle cells. J Appl Physiol 2001; 91: 1372-1379.

38 Brown JK, Jones CA, Rooney LA, Caughey GH, Hall IP. Tryptase's potent mitogenic effects in human airway smooth muscle cells are via nonproteolytic actions. Am J Physiol Lung Cell Mol Physiol 2002; 282: L197-L206.

39 Venkayya R, Lam M, Willkom M, Grunig G, Corry DB, Erle DJ. The Th2 lymphocyte products IL-4 and IL-13 rapidly induce airway hyperresponsiveness through direct effects on resident airway cells. Am J Respir Cell Mol Biol 2002; 26: 202-208.

40 Thomas PS, Yates DH, Barnes PJ. Tumor necrosis factoralpha increases airway responsiveness and sputum neutrophilia in normal human subjects. Am J Respir Crit Care Med 1995; 152: 76-80. 
41 Thomas PS, Heywood G. Effects of inhaled tumour necrosis factor alpha in subjects with mild asthma. Thorax 2002; 57: 774-778.

42 Berry MA, Hargadon B, Shelley M, et al. Evidence of a role of TNF $\alpha$ in refractory asthma. $N$ Engl J Med 2006; 354: 697-708.

43 Howarth PH, Babu KS, Arshad HS, et al. Tumour necrosis factor $(\mathrm{TNF} \alpha)$ as a novel therapeutic target in symptomatic corticosteroid-dependent asthma. Thorax 2005; 60: 1012-1018.

44 Bradding $\mathrm{P}$, Feather $\mathrm{IH}$, Howarth $\mathrm{PH}$, et al. Interleukin 4 is localized to and released by human mast cells. J Exp Med 1992; 176: 1381-1386.

45 Kobayashi H, Okayama Y, Uno D, et al. IL-13 mRNA expression and IL-13 production in human lung mast cells. J Allergy Clin Immunol 1997; 99: S91.
46 Gibbs BF, Arm JP, Gibson K, Lee TH, Pearce FL. Human lung mast cells release small amounts of interleukin- 4 and tumour necrosis factor-alpha in response to stimulation by anti-IgE and stem cell factor. Eur J Pharmacol 1997; 327: 73-78.

47 Chhabra J, Li Y-Z, Alkhouri $\mathrm{H}$, et al. Histamine and tryptase modulate asthmatic airway smooth muscle GMCSF and RANTES release. Eur Respir J 2007; 29: 861-870.

48 Giembycz MA, Newton R. Beyond the dogma: novel $\beta 2$ adrenoceptor signalling in the airways. Eur Respir J 2006; 27: 1286-1306.

49 Duffy SM, Cruse G, Lawley WJ, Bradding P. Beta2adrenoceptor regulation of the $\mathrm{K}+$ channel $\mathrm{IK}_{\mathrm{Ca}} 1$ in human mast cells. FASEB J 2005; 19: 1006-1008.

50 Liu G, Shi J, Yang L, et al. Assembly of a Ca2+-dependent BK channel signaling complex by binding to beta2 adrenergic receptor. EMBO J 2004; 23: 2196-2205. 